\title{
A cukorbetegség és a daganatos thrombocytosis túlélésre gyakorolt hatásának vizsgálata emlőtumoros nőkben
}

\author{
Somogyi Anikó dr. ${ }^{1}$ - Herold Magdolna ${ }^{1}$ - Lohinszky Júlia dr. ${ }^{1}$ \\ Harsányi László dr. ${ }^{2}$. Herold Zoltán MSc. ${ }^{1}$ \\ ${ }^{1}$ Semmelweis Egyetem, Általános Orvostudományi Kar, II. Belgyógyászati Klinika, Budapest \\ ${ }^{2}$ Semmelweis Egyetem, Általános Orvostudományi Kar, I. Sebészeti Klinika, Budapest
}

\begin{abstract}
Bevezetés: Számos daganatban igazolták, hogy mind a thrombocytosis, mind a 2-es típusú cukorbetegség negatívan befolyásolja a tumoros betegek túlélését. A két tényező szerepét együttesen emlőtumorokban eddig még nem vizsgálták.

Célkitüés: Vizsgálatunk célja a Semmelweis Egyetem II. sz. Belgyógyászati Klinika, illetve az I. sz. Sebészeti Klinika szakambulanciáin 2014-2017 között emlőtumor miatt kezelt betegpopulációban a thrombocytosis és a 2-es típusú diabetes gyakoriságának és a daganatos betegség kimenetelére gyakorolt önálló és együttes hatásának felmérése volt. Vizsgáltuk az emlőtumor diagnózisakor a laboratóriumi és anamnesztikus adatokat a cukorbeteg és nem cukorbeteg csoportokban, túléléselemzéssel a thrombocytosis és/vagy a 2-es típusú cukorbetegség túlélést befolyásoló hatását. Módszer: Retrospektív vizsgálatunkban 274, emlőtumoros beteg adatait elemeztük. A betegeket legkésőbb 2018. 12. 31-ig, az utolsó egyetemi megjelenésükig vagy haláluk bekövetkeztéig követtük.

Eredmények: Emelkedett thrombocytaszámokat (400 G/1 feletti) a betegek 5\%-ában figyeltünk meg. A betegek közel ötöde 2 -es típusú cukorbeteg volt ( 52 fö). A cukorbetegek szignifikánsan idősebbek voltak a tumor felismerésekor (nem cukorbeteg: 56,8 $\pm 13,8$ év, cukorbeteg: 67,8 $\pm 11,0$ év, p<0,0001). A nem cukorbetegeknél gyakoribb a tripla negatív ( $\mathrm{p}=0,0366)$, illetve a Tl-es stádiumú tumor $(50 \%)$, míg cukorbetegekben a T2-es stádium a leggyakoribb $(51,9 \%)$. A túlélési modell alapján az emlőtumoros betegek rövidebb túlélési idejét prognosztizálja, ha 2 -es típusú cukorbetegségben is szenvednek $(\mathrm{p}=0,0032)$. Vizsgálatunkban a betegek túlélését a thrombocytosis nem befolyásolta.

Következtetés: A 2-es típusú cukorbetegekben az emlőtumor diagnosztizálásakor súlyosabb klinikai stádium valószínűsíthető, és rövidebb túlélés prognosztizálható. Javasoljuk, hogy a cukorbeteg nők kontrollvizsgálata alkalmával a nók figyelmét fel kell hívni a mammográfiai szúrővizsgálatok fontosságára, illetve 30 éves kor felett a diabetest rizikótényezőnek kell tekinteni, és a betegek szürővizsgálata legalább kétévente javasolt.
\end{abstract}

Orv Hetil. 2019; 160(51): 2012-2020.

Kulcsszavak: vérlemezkék, thrombocytosis, emlőneoplazmák, 2-es típusú diabetes mellitus, túléléselemzés

\section{Survival impact of diabetes and paraneoplastic thrombocytosis in women with breast cancer}

Introduction: Thrombocytosis and type 2 diabetes have negative effect on the survival of tumor patients. Previously, their joint effect has not been studied in breast cancer.

Aim: The aim of our retrospective study was to investigate the occurrence and effects of thrombocytosis and/or type 2 diabetes in breast cancer patients who attended the 2 nd Department of Internal Medicine or the 1st Department of Surgery, Semmelweis University, between 2014 and 2017. Laboratory and anamnestic data were compared at the time of tumor diagnosis between diabetic and non-diabetic groups. Survival analysis was performed to study the effects of thrombocytosis and/or type 2 diabetes.

Method: 274 study participants were followed until 31 December 2018, or until their last appearance at the University, or until their death. 
Results: $5 \%$ of the patients had elevated platelet counts (over $400 \mathrm{G} / \mathrm{L}$ ), and 52 were diabetics. Diabetics were significantly older (non-diabetics: $56.8 \pm 13.8$ years, diabetics: $67.8 \pm 11.0$ years, $\mathrm{p}<0.0001$ ). Triple negative subtype $(\mathrm{p}=0.0366)$, and $\mathrm{T} 1$ stage $(50 \%)$ were present more often in non-diabetics. Stage T2 was more common in diabetic patients $(51.9 \%)$. Type 2 diabetes was associated with a shorter survival time $(\mathrm{p}=0.0032)$. Thrombocytosis did not affect patient survival.

Conclusion: At the diagnosis of breast cancer, existing type 2 diabetes is associated with a more severe clinicopathological stage and shorter survival. We recommend that during routine diabetes controls, women should be made aware of the importance of mammography screening. Moreover, diabetes should be considered as a risk factor; after 30 years of age, diabetics should be screened at least every two years.

Keywords: blood platelets, thrombocytosis, breast neoplasms, type 2 diabetes mellitus, survival analysis

Somogyi A, Herold M, Lohinszky J, Harsányi L, Herold Z. [Survival impact of diabetes and paraneoplastic thrombocytosis in women with breast cancer]. Orv Hetil. 2019; 160(51): 2012-2020.

(Beérkezett: 2019. július 22.; elfogadva: 2019. augusztus 17.)

\section{Rövidítések}

BRCA $=$ (breast cancer susceptibility gene $)$ emlődaganat-fogékonysági gén; CKD-EPI = (chronic kidney disease-epidemiology collaboration) krónikus vesebetegség-epidemiológiai együttmúködés; DCIS = ductalis carcinoma in situ; eGFR = (estimated glomerular filtration rate) számított glomerulusfiltrációs ráta; $\mathrm{HbA}_{\mathrm{lc}}=$ hemoglobin-A-lc; $\mathrm{HER} 2=$ (human epidermal growth factor receptor 2) humán epidermális növekedési faktor receptor- 2 ; HR = (hazard ratio) hazárd ráta; IGFl = (insulin-like growth factor 1$)$ inzulinszerü növekedési faktor- $1 ; \mathrm{KI}=$ konfidenciaintervallum; KSH $=$ Központi Statisztikai Hivatal; LCIS = lobularis carcinoma in situ; $\mathrm{LFU}=($ lost to follow-up) a követés során elveszett; T2DM = (type 2 diabetes mellitus) 2 -es típusú diabetes mellitus; TIA $=$ (transient ischemic attack) átmeneti ischaemiás roham; TNM = daganatok stádiumbeosztása (tumor, lokális nyirokcsomó-áttét, távoli metasztázis)

Az emlőtumor világszerte a nők halálozásának második leggyakoribb oka: évente kb. másfél millió új esetet diagnosztizálnak, és kb. évi 500 000, emlötumor miatti halálesetet regisztrálnak [1]. A Központi Statisztikai Hivatal és az Országos Onkológiai Intézet, Nemzeti Rákregiszter 2018. augusztusi, revideált adatai alapján Magyarországon 8272 új emlőtumoros esetet regisztráltak 2015-ben, aminek alapján az emlőtumoros betegek aránya 197 fó 100000 női lakosra számolva [2]. A betegség kialakulásában szerepet játszhatnak örökletes és/ vagy környezeti tényezők is. A BRCAl és -2 tumorszuppresszor gének mutációja örökletesen okozhat melldaganatot. A cukorbetegség, az életkor, a korai menarche, a nulliparitás, a szoptatás hiánya, a D-vitamin hiánya és a túlsúly hajlamosíthat a daganatképződésre [3-5].

Az emlődaganatok két nagy csoportját az ún. invazív, illetve a noninvazív formák alkotják. A noninvazív mellrák a kiindulási helyétől, a lobulustól vagy a ductustól nem távolodik el, ilyen például a lobularis carcinoma in situ (LCIS) vagy a ductalis carcinoma in situ (DCIS). Amennyiben a lobulusból vagy a ductusból a daganat az emlő környező szöveteibe terjed, invazívnak nevezzük. Megkülönböztetünk invazív lobularis és ductalis carcinomát, medullaris, mucinosus és tubularis carcinomát, inflammatoricus mellrákot, az emlő Paget-megbetegedését és phylloid tumort. Az emlőtumorok áttétei a leggyakrabban az agyban, a májban, a tüdőben és a csontokban figyelhetők meg [5].

2017-ben az Amerikai Sebészeti Társaság (American College of Surgeons) frissítette az emlőtumor stádiumbesorolásának irányelveit azáltal, hogy a korábbi TNMrendszert kiegészítette további paraméterekkel: ezek közé tartozik a tumorgradus, az ösztrogén-progeszteron receptor statusa, a humán epidermális növekedési faktor receptor-2 (HER2) statusa és az onkotípus-DX-pontrendszer, mely utóbbival genomikai teszt alapján következtetni lehet arra, hogy milyen valószínúséggel recidivál a daganat, mennyire lesz hatékony a kemoterápia és a radioterápia. Ezen tényezőkkel a mellrákok stádiumba való besorolása sokkal bonyolultabbá, de egyben sokkal pontosabbá is vált [4-6].

Számos daganattípusról igazolták, hogy jelentős hányadában a betegeknél emelkedett thrombocytaszám figyelhető meg, azaz thrombocytosis alakul ki. A magasabb thrombocytaszámú esetekhez jellemzően rosszabb túlélési esélyek tartoznak [7]. Az emlőtumorok esetében a legtöbb vizsgálat eredménye alapján thrombocytosis nem vagy csak nagyon kis számban alakul ki $[7,8]$. Harano és mtsai felvetették [9], hogy a többi tumorformához képest az inflammatoricus emlőtumorokban a thrombocytosis aránya magasabb.

A cukorbetegség jelentős egészségügyi és gazdasági probléma, világszerte a lakosság kb. 8-9\%-a diabeteses. A betegek mintegy 90\%-a 2-es típusú cukorbeteg (T2DM) [10]. Nemzetközi becslések alapján a 60 év feletti korosztályban kb. minden ötödik személy szenved T2DM-ben [11]. A KSH 2017-es adatai alapján a teljes magyar lakosság kb. 11,8\%-a 2-es típusú cukorbeteg, míg a 60 éves és idősebb korosztályban megközelítőleg a lakosság harmada szenved T2DM-ben [2]. 
A tumoros betegségek gyakoribb kialakulását igazolták T2DM-ben az egészséges populációhoz képest: szignifikánsan több emlő-, vastag- és végbél-, illetve hasnyálmirigytumoros esetet figyeltek meg [12]. Számos elmélet született [13], hogy T2DM-ben a tumoros betegségek szignifikánsan magasabb gyakorisága mögött a T2DMre specifikus hatások állhatnak, mint például a hyperglykaemia, az inzulinrezisztencia, a hyperinsulinaemia, az inzulinszerü növekedési faktor-1 (IGFl) magasabb koncentrációja a szérumban, a folyamatos gyulladásos állapotok miatti magasabb citokinkoncentrációk, az oxidatív stressz, a dislipidaemia vagy a fokozott thrombocytaaktiváció [13-18]. A cukorbeteg emlőtumoros betegekben a tumor kialakulásában kiemelt szerepet tulajdonítanak a glykaemiás kontrollnak, illetve a megnövekedett menynyiségü inzulinnak és az IGFl-nek is mint mitogéneknek: a nagyobb mennyiségű inzulin és IGFl által aktivált receptorok számos tumoros növekedést serkentő útvonalat indít $(\mathrm{h}) \mathrm{a}(\mathrm{t})$ nak be $[3,19,20]$.

\section{A vizsgálat célja}

Vizsgálatunk során arra kerestük a választ, hogy a Semmelweis Egyetem II. Belgyógyászati Klinikájának Onkológiai Ambulanciáján, illetve a Semmelweis Egyetem I. Sebészeti Klinikájának Sebészeti Szakambulanciáján a 2014 és 2017 között vizsgált és kezelt, emlőtumorban szenvedő betegpopulációban milyen arányban fordul elő a T2DM és a thrombocytosis. Vizsgáltuk továbbá: milyen laboratóriumi és anamnesztikus adatokkal rendelkeztek a betegek a tumor felfedezésekor? Van-e kimutatható különbség a nem T2DM tumoros és a T2DM tumoros betegek paraméterei között? Túlélési modellek segítségével igazolható-e, hogy a T2DM és/vagy a thrombocytosis az emlőtumoros betegek túlélését befolyásoló tényező?

\section{Módszer}

\section{Betegek}

Retrospektív kohorszvizsgálatunkat a Semmelweis Egyetem II. Belgyógyászati Klinikájának Onkológiai Ambulanciáján és I. Sebészeti Klinikájának Sebészeti Szakambulanciáján 2014 és 2017 között diagnosztizált, összesen 274 , emlőtumor miatt kezelt nóbeteg - a tumor felfedezésekor rögzített - archív klinikai adatainak felhasználásával végeztük. Kizáró kritériumok voltak az egyéb, korábbi tumoros megbetegedések, súlyos vérképző szervi megbetegedések, transzplantáció, autoimmun betegségek, szisztémás szteroid- és egyéb immunszuppresszív terápia. A kiértékelt laboratóriumi vizsgálatok a tumor sebészi eltávolítása és/vagy bárminemú radiokemoterápiás kezelés megkezdése előtt történtek.

A vizsgált betegeknél a primer tumor felfedezésekor rögzítettük adatbázisunkban a vérképet - különös tekin- tettel a thrombocytaértékekre -, az éhomi vércukorszinteket, a máj- és vesefunkció paramétereit, valamint a T2DM fennállási idejét, a betegeknek a tumor felfedezését követő túlélési idejét. A laboratóriumi paraméterek mellett felmértük a betegeknél a tumoros betegség mellett jelen lévő egyéb betegségek, mint például a magas vérnyomás, pajzsmirigybetegségek, major cardiovascularis események (stroke, myocardialis infarctus stb.) és a TIA elöfordulását is.

A cukorbetegek általános cukoranyagcsere-állapotát a glikált hemoglobin $\left(\mathrm{HbA}_{\mathrm{lc}}\right)$ értékeivel jellemezhetjük a legjobban. Az archív adatok között igen kevés esetben történt $\mathrm{HbA}_{1 \mathrm{c}}$-mérés, emiatt ennek a többi paraméterrel történő összehasonlítását jelen vizsgálatunkban nem tudtuk elvégezni.

A laboratóriumi leleteken a számított glomerulusfiltrációs ráta (eGFR) értéke $90 \mathrm{ml} / \mathrm{min} / 1,73 \mathrm{~m}^{2}$ felett (a régebbi leleteken $60 \mathrm{ml} / \mathrm{min} / 1,73 \mathrm{~m}^{2}$ felett) általában nincs feltüntetve. Emiatt a pontos eGFR-értékeket minden esetben manuálisan, a CKD-EPI-képlet segítségével [21] számítottuk ki.

\section{Statisztikai elemzések}

Statisztikai elemzéseinket az $\mathrm{R}$ for Windows version 3.6.1 (R Foundation for Statistical Computing, 2019, Bécs, Ausztria) környezetben végeztük. Az adatelemzés során a hazai normál populáció összehasonlítását a mintapopulációval $\chi^{2}$-illeszkedés-vizsgálattal, a csoportok közötti összehasonlításokat pedig kétmintás Welch-féle t-próbával, illetve Fisher-féle egzakt teszttel végeztük $[22,23]$. A többszörös összehasonlítások esetében a pértékek korrekciója a 'false discovery rate' (hamis találati arány) módszerrel történt [24].

\section{Túléléselemzés}

A betegek túlélési idejét a betegség felfedezésétől a beteg haláláig; a követés során elveszett (LFU) betegek esetében a legutolsó, bármelyik egyetemi klinikán történt megjelenésükig vagy a túlélő betegeknél legkésőbb 2018. december 31-ig számoltuk. A túlélési adatok elemzését az okspecifikus hazárdokon alapuló nem paraméteres 'competing risk' túlélési modell segítségével ( $\mathrm{R}$ mstate $[25,26]$ és survival [27] csomag) végeztük el.

\section{Etikai engedély}

A fenti vizsgálatokat az Egészségügyi Tudományos Tanács Tudományos és Kutatásetikai Bizottsága (ETT TUKEB, engedélyszám: 8951-3/2015/EKU) és a Semmelweis Egyetem Tudományos Etikai Bizottsága (SE TUKEB, engedélyszám: 21-13/1994, utolsó módosítás kelte: 2019. január 15.) is engedélyezte. 


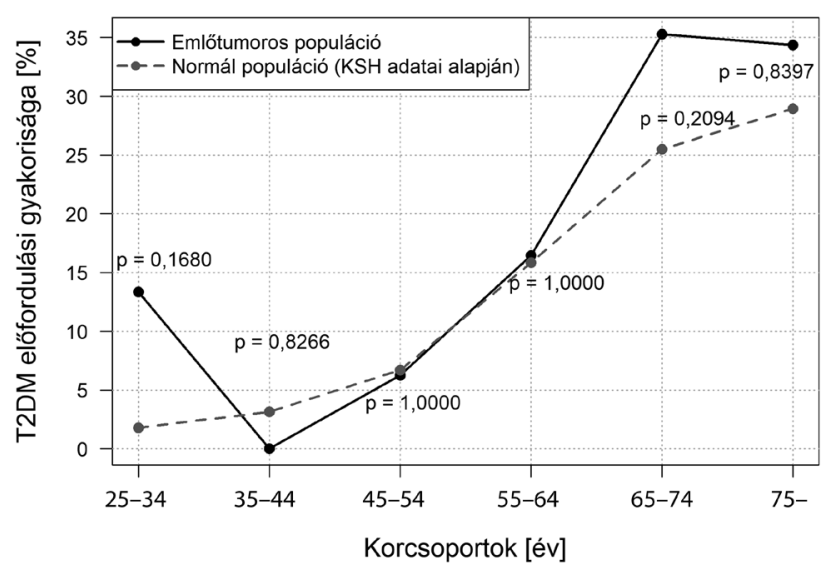

1. ábra

\begin{abstract}
A 2-es típusú cukorbetegség (T2DM) előfordulási gyakorisága a mintapopulációban és a normál populációban, az egyes korcsoportokban, nőkben. A normál populációra vonatkozó adatok forrása a Központi Statisztikai Hivatal „Egészségügyi Statisztikai Évkönyv, 2017" címú kiadványa [2]. A 25-34 éves korcsoportba az emlótumoros betegek $\sim 5 \%$-a tartozott, ahol a 15-ból 2 fó volt 2 -es típusú cukorbeteg. A normál populációhoz képest ebben a korcsoportban a jelentősen magasabbnak túnő előfordulási gyakoriság csupán az alacsony esetszámnak tudható be
\end{abstract}

\section{Eredmények}

Retrospektív vizsgálatunkban 274 , emlőcarcinomában szenvedő nőbeteg, a daganat felfedezésekor elvégzett laboratóriumi és anamnesztikus adatait elemeztük. A betegeket a T2DM megléte alapján 2 csoportba rendeztük: a ukorbetegségben nem szenvedő 222 fö a nem-DMcsoportba került, míg az 52 cukorbeteg személy a T2DM-csoportba lett besorolva.

Az adatok elemzését elvégeztük aszerint is, hogy a betegeket a thrombocytosis megléte avagy hiánya szerint csoportosítottuk. A thrombocytosis meghatározása nem egységes, az irodalomban ez ideig [28] számos lehetséges thrombocytosis-határértéket definiáltak, melyek közül többet az abszolút thrombocytaszám normáltartományán [29] belül határoztak meg. A fenti határértékek közül, ha a thrombocytosis diagnózisát a normáltartomány felső határán, azaz 400 G/1 thrombocytaszám felett definiáltuk, a betegek csupán kis hányadánál volt igazolható a thrombocytosis (14 fo', 5,1\%). A thrombocytosisos és nem thrombocytosisos betegek laboratóriumi és anamnesztikus paraméterei nem különböztek egymástól.

\section{A cukorbeteg és a nem cukorbeteg csoport összehasonlitása}

A T2DM előfordulása az adatelemzésbe bevonható, értékelhetô esetek 19\%-ában (52 fó a 274-ból) volt megfigyelhető. Az emlőtumor mellett T2DM-ben is szenvedő betegekben a diabetes a tumor diagnózisát megelőzően átlagosan 7,4 $\pm 8,3$ (átlag \pm szórás) évvel korábban alakult ki. Korcsoport szerint elemezve és a normál magyarországi populációval [2] összehasonlítva a vizsgált emlő- tumoros betegekben a T2DM előfordulása az egyes korcsoportokban nem különbözött szignifikánsan (1. ábra).

T2DM-ben a tumor kialakulása szignifikánsan későbbi életkorban volt megfigyelhető, mint a nem-DM-csoportban $(\mathrm{p}<0,0001)$. A laboratóriumi paraméterek összehasonlításakor az éhgyomri vércukorszintek $(\mathrm{p}<0,0001)$ kivételével a két csoport között nem igazoltunk további különbségeket (1. táblázat).

Cukorbetegekben az emlőtumorok előrehaladottabb állapotát figyeltük meg: a nem-DM-csoportban Tl-stádiumú tumor a betegek felében, T2-stádiumú pedig $\mathrm{kb}$. harmadában $(34,2 \%)$ fordult elő. T2DM mellett ez az arány fordított volt, a Tl-stádium a betegek $28,8 \%$-ában

\section{1. táblázat $\mid$ Az emlótumoros (nem-DM), illetve az emlőtumoros és 2-es tí- pusú cukorbetegségben (T2DM) is szenvedő betegek életkorá- nak, laboratóriumi paramétereinek és az átlagos túlélési idők összehasonlítása (átlag \pm szórás)}

\begin{tabular}{lccc}
\hline & $\begin{array}{c}\text { Nem-DM } \\
(\mathrm{n}=222)\end{array}$ & $\begin{array}{c}\text { T2DM } \\
(\mathrm{n}=52)\end{array}$ & p-érték \\
\hline Életkor [év] & $56,8 \pm 13,8$ & $67,8 \pm 11,0$ & $p<0,0001$ \\
\hline Fehérvérsejtszám [G/1] & $7,14 \pm 2,24$ & $7,66 \pm 1,94$ & $\mathrm{p}=0,3035$ \\
\hline Vörösvértestszám [T/1] & $4,60 \pm 0,39$ & $4,59 \pm 0,48$ & $\mathrm{p}=0,9100$ \\
\hline Hemoglobin [g/l] & $134,9 \pm 12,2$ & $133,9 \pm 15,5$ & $\mathrm{p}=0,9100$ \\
\hline Hematokrit [l/1] & $0,40 \pm 0,04$ & $0,40 \pm 0,04$ & $\mathrm{p}=0,9100$ \\
\hline $\begin{array}{l}\text { Vörösvértest-térfogat } \\
\text { (MCV) [fl] }\end{array}$ & $87,8 \pm 4,6$ & $88,0 \pm 6,1$ & $\mathrm{p}=0,9100$ \\
\hline $\begin{array}{l}\text { Vörösvértest-hemoglo- } \\
\text { binkoncentráció (MCH) } \\
\text { [pg] }\end{array}$ & $29,4 \pm 1,8$ & $29,3 \pm 4,5$ & $\mathrm{p}=0,9100$ \\
\hline
\end{tabular}

Vörösvértest átlagos hemoglobinkoncentráci-

ója (MCHC) [g/l]

\begin{tabular}{lccc}
\hline $\begin{array}{l}\text { Vörösvértest-eloszlási } \\
\text { szélesség (RDW) [\%] }\end{array}$ & $13,5 \pm 1,1$ & $13,7 \pm 1,1$ & $\mathrm{p}=0,6828$ \\
\hline Thrombocytaszám [G/1] & $274,5 \pm 70,0$ & $257,5 \pm 57,6$ & $\mathrm{p}=0,2819$ \\
\hline $\begin{array}{l}\text { Glutamát-oxálacetát- } \\
\text { transzamináz (GOT) }\end{array}$ & $24,7 \pm 32,9$ & $25,3 \pm 11,7$ & $\mathrm{p}=0,9100$ \\
{$[\mathrm{U} / \mathrm{l}]$} & & &
\end{tabular}

Glutamát-piruvát-ami- $\quad 23,7 \pm 43,2 \quad 24,7 \pm 10,6 \quad \mathrm{p}=0,9100$ notranszferáz (GPT)

$[\mathrm{U} / 1]$

Gamma-glutamil-transz- $\quad 29,2 \pm 38,8 \quad 43,0 \pm 47,2 \quad \mathrm{p}=0,2819$ feráz (GGT) [U/1]

\begin{tabular}{|c|c|c|c|}
\hline Kreatinin $[\mu \mathrm{mol} / \mathrm{l}]$ & $67,0 \pm 16,2$ & $67,4 \pm 15,3$ & $\mathrm{p}=0,9100$ \\
\hline $\begin{array}{l}\text { Számított glomerulusfilt- } \\
\text { rációs ráta (eGFR) [ml/ } \\
\left.\text { min } / 1,73 \mathrm{~m}^{2}\right]\end{array}$ & $88,1 \pm 19,4$ & $80,9 \pm 18,6$ & $\mathrm{p}=0,1314$ \\
\hline $\begin{array}{l}\text { Éhomi vércukor } \\
{[\mathrm{mmol} / 1]}\end{array}$ & $5,17 \pm 0,48$ & $8,00 \pm 3,27$ & $p<0,0001$ \\
\hline Koleszterin $[\mathrm{mmol} / \mathrm{l}]$ & $4,64 \pm 0,75$ & $4,80 \pm 1,06$ & $\mathrm{p}=0,6828$ \\
\hline $\begin{array}{l}\text { Diabetes fennállási ideje } \\
\text { [év] }\end{array}$ & - & $7,4 \pm 8,3$ & - \\
\hline
\end{tabular}

Átlagos túlélési idő $\quad 49,0 \pm 24,8 \quad 49,6 \pm 36,6 \quad \mathrm{p}=0,9100$ [hónap] 
Az emlőtumoros (nem-DM), illetve az emlőtumoros és 2-es típusú cukorbetegségben (T2DM) is szenvedő nők anamneszti kus adatainak összehasonlítása (megfigyelt esetszám, illetve csoporton belüli százalékos arány)

\begin{tabular}{lccc}
\hline & $\begin{array}{c}\text { Nem-DM } \\
(\mathrm{n}=222)\end{array}$ & $\begin{array}{l}\text { T2DM } \\
(\mathrm{n}=52)\end{array}$ & p-érték \\
\hline Tumor oldalisága & & & \\
- Bal & $99(44,6 \%)$ & $26(50 \%)$ & \\
- Jobb & $120(54 \%)$ & $26(50 \%)$ & $\mathrm{p}=0,8122$ \\
- Mindkettő & $3(1,4 \%)$ & $0(0 \%)$ & \\
\hline TNM-stádium & & & \\
(tumorméret) & & & \\
- Mútét nem volt & $9(4,1 \%)$ & $4(7,7 \%)$ & \\
- T1 & $111(50 \%)$ & $15(28,8 \%)$ & \\
- T2 & $76(34,2 \%)$ & $27(51,9 \%)$ & $p=0,0429$ \\
- T3 & $18(8,1 \%)$ & $2(3,8 \%)$ & \\
- T4 & $8(3,6 \%)$ & $4(7,7 \%)$ & \\
\hline
\end{tabular}

TNM-stádium

(nyirokcsomóáttét)

- Mütét nem volt $\quad 9(4,1 \%) \quad 4(7,7 \%)$

- N0

$-\mathrm{Nl}$

$-\mathrm{N} 2$

$-\mathrm{N} 3$

$115(51,8 \%) \quad 24(46,2 \%)$

$71(32 \%) \quad 15(28,8 \%) \quad \mathrm{p}=0,4989$

$19(8,6 \%) \quad 8(15,4 \%)$

$8(3,6 \%) \quad 1(2 \%)$

\begin{tabular}{lccc}
\hline Távoli áttét & $56(25,2 \%)$ & $21(40,4 \%)$ & $\mathrm{p}=0,0941$ \\
\hline HER2-pozitív & $70(31,5 \%)$ & $14(26,9 \%)$ & $\mathrm{p}=0,7148$ \\
\hline $\begin{array}{l}\text { Ösztrogénreceptor-pozitív } \\
176(79,3 \%)\end{array}$ & $44(84,6 \%)$ & $\mathrm{p}=0,5371$ \\
\hline $\begin{array}{l}\text { Progeszteronreceptor- } \\
\text { pozitív }\end{array}$ & $143(64,4 \%)$ & $39(75 \%)$ & $\mathrm{p}=0,2489$ \\
\hline
\end{tabular}

\begin{tabular}{|c|c|c|c|}
\hline Tripla negatív & $32(14,4 \%)$ & $1(2 \%)$ & $p=0,0366$ \\
\hline $\begin{array}{l}\text { Szövettani típus } \\
\text { - Ductalis } \\
\text { - Lobularis } \\
\text { - Egyéb típusok }\end{array}$ & $\begin{array}{c}174(78,4 \%) \\
31(14 \%) \\
17(7,7 \%)\end{array}$ & $\begin{array}{r}38(73,1 \%) \\
7(13,5 \%) \\
7(13,5 \%)\end{array}$ & $\mathrm{p}=\mathrm{c}$ \\
\hline Magas vérnyomás & $72(32,4 \%)$ & $33(63,5 \%)$ & $p=0,0004$ \\
\hline $\begin{array}{l}\text { Cardiovascularis események } \\
\text { - Akut myocardialis } \\
\text { infarctus } \\
\text { - Preventív CABG / PCI } \\
\text { - Egyéb szignifikáns } \\
\text { nagyérbetegség } \\
\text { - Stroke }\end{array}$ & $\begin{array}{l}1(0,5 \%) \\
0(0 \%) \\
11(5 \%) \\
3(1,4 \%)\end{array}$ & $\begin{array}{l}5(9,6 \%) \\
0(0 \%) \\
3(5,8 \%) \\
3(5,8 \%)\end{array}$ & $\begin{array}{l}p=0,0062 \\
\mathrm{p}=1,0000 \\
\mathrm{p}=1,0000 \\
\mathrm{p}=0,1634\end{array}$ \\
\hline $\begin{array}{l}\text { Átmeneti ischaemiás roham } \\
\text { (TIA) }\end{array}$ & $3(1,4 \%)$ & $3(5,8 \%)$ & $\mathrm{p}=0,1634$ \\
\hline Pajzsmirigybetegség & $27(12,2 \%)$ & $9(17,3 \%)$ & $\mathrm{p}=0,2819$ \\
\hline Thrombocytosis & $14(6,3 \%)$ & $0(0 \%)$ & $\mathrm{p}=0,1634$ \\
\hline $\begin{array}{l}\text { Aggregációgátló kezelés- } \\
\text { ben részesült }\end{array}$ & $8(3,6 \%)$ & $15(28,8 \%)$ & $p<0,0001$ \\
\hline $\begin{array}{l}\text { Cenzor } \\
\text { - Tumor miatt elhunyt } \\
\text { - LFU + egyéb okból } \\
\text { elhunyt } \\
\text { - Túlélt }\end{array}$ & $\begin{array}{c}7(3,2 \%) \\
195(87,8 \%)\end{array}$ & $\begin{array}{c}13(25 \%) \\
4(7,7 \%) \\
35(67,3 \%)\end{array}$ & $p=0,0074$ \\
\hline
\end{tabular}

HER2 = humán epidermális növekedési faktor receptor-2; CABG = coronariaáthidaló műtét; $\mathrm{PCI}=$ perkután coronariaintervenció; $\mathrm{LFU}=$ a követés során elveszett
(15 fö), a T2 pedig az 52-ből 27 fó (51,9\%) esetében fordult elő $(\mathrm{p}=0,0429)$. A T3- és T4-stádiumú tumorok aránya a két csoportban közel azonos volt (2. táblá$z a t)$. A lokális nyirokcsomó- $(\mathrm{p}=0,4989)$ és a távoli áttétek $(\mathrm{p}=0,0941)$ előfordulása nem különbözött a csoportok között, ahogy a tumorok HER2- $(\mathrm{p}=$ $0,7148)$, progeszteron- $(\mathrm{p}=0,2489)$, illetve ösztrogénreceptor-státusza $(\mathrm{p}=0,5371)$ között sem igazoltunk különbséget. A tripla negatív emlötumorok a T2DMcsoportban szignifikánsan kevesebbszer fordultak elő $(\mathrm{p}=0,0366)$.

A T2DM-ben gyakran kialakuló társbetegségek előfordulásait vizsgálva a T2DM-csoportban kétszer olyan gyakran fordult elö a hypertonia $(\mathrm{p}=0,0004)$, illetve arányaiban szignifikánsan többször estek át a cukorbetegek akut myocardialis infarctuson a tumor kialakulását megelőzően $(p=0,0062)$, mint a nem cukorbetegek. Diabetesben a preventív céllal alkalmazott aggregációgátló kezelést szignifikánsan gyakrabban alkalmazták, mint a nem-DM-csoportban $(\mathrm{p}<0,0001)$. A további vizsgált társbetegségek előfordulásai nem különböztek a két csoport között (2. táblázat).

\section{A betegek túlélési adatainak elemzése}

Jelen vizsgálatunk során két különböző végpontot definiáltunk: az első végpont a biztosan az emlőtumor miatt bekövetkező halálok volt. Az alacsonyabb esetszám miatt a második végpontba pedig összevontuk azon eseteket, amikor a beteg kezelése valamilyen ok miatt nem az Egyetem klinikáin, hanem például a területi ellátásban történt, vagy a beteg saját döntése miatt nem kívánt semmilyen kezelésben részesülni, illetve ha a beteg elhunyt, de a halál oka nem volt az emlőtumorra visszavezethető. A második végpontba sorolt betegek a legtöbbször a területi ellátásba kerültek át, és további nyomon követésük emiatt nem volt lehetséges. Erre a végpontra a későbbiekben mint LFU (a követés során elveszett) fogunk hivatkozni.

A betegek túlélési idejét az emlőtumor diagnózisától kezdődően számítottuk, a vizsgálat ideje alatt túlélt betegeknél a követés legkésőbb 2018. december 31-ig történt. Összesen 33 beteg (12\%) hunyt el biztosan az emlőtumor progressziója miatt, közülük 20-an a nem-DM-csoportba (9\%) és 13-an a T2DM-csoportba (25\%) tartoztak $(\mathrm{p}=0,0074)$. Az LFU végpontot 11 (4\%) betegnél figyeltük meg (2. táblázat).

Az okspecifikus hazárdok módszerén alapuló 'competing risk' modellek legnagyobb erényét kihasználva, vagyis hogy ugyanazon modellen belül egyszerre több végpont bekövetkezésének korrigált elemzése lehetséges, meghatároztuk a thrombocytosis és a T2DM önálló, illetve közös hatását is a tumoros halálozás és az LFU végpontokra. A modellek eredményeinek bemutatását a jobb érthetôség kedvéért az alábbi módszer szerint közöljük: mivel az LFU eseményt a modellekben csupán mint „az emlőtumor miatti halálozás pontosabb megha- 
3. táblázat | 'Competing risk' túlélési modellek eredményei

\begin{tabular}{llll|ll}
\hline & A modell magyarázó változói & Emlötumor miatti halálozás & & A követés során elveszett (LFU) \\
\cline { 3 - 6 } & & $\mathrm{HR}(95 \% \mathrm{KI})$ & $\mathrm{p}$-érték & $\mathrm{HR}(95 \% \mathrm{KI})$ & $\mathrm{p}$-érték \\
\hline 1. & T2DM & $2,87(1,43-5,78)$ & $\mathrm{p}=0,0032$ & $2,61(0,76-8,91)$ & $\mathrm{p}=0,1262$ \\
\hline 2. & Thrombocytosis & $1,17(0,28-4,89)$ & $\mathrm{p}=0,8300$ & $0,00(0,00-\infty)$ & $\mathrm{p}=0,9970$ \\
\hline 3. & Abszolút thrombocytaszám & $1,002(0,998-1,007)$ & $\mathrm{p}=0,339$ & $0,996(0,986-1,005)$ & $\mathrm{p}=0,3710$ \\
\hline 4. & T2DM és & $2,98(1,46-6,10)$ & $p=0,0027$ & $2,44(0,72-8,35)$ & $\mathrm{p}=0,1541$ \\
& Thrombocytosis & $1,62(0,38-6,98)$ & $\mathrm{p}=0,5179$ & $0,00(0,00-\infty)$ & $\mathrm{p}=0,9970$ \\
\hline 5. & T2DM és & $3,09(1,52-6,30)$ & $p=0,0019$ & $2,47(0,72-8,49)$ & $\mathrm{p}=0,1517$ \\
& Abszolút thrombocytaszám & $1,003(0,999-1,008)$ & $\mathrm{p}=0,1731$ & $0,996(0,986-1,006)$ & $\mathrm{p}=0,4406$ \\
\hline
\end{tabular}

$\mathrm{HR}=$ hazárd ráta; $\mathrm{KI}=$ konfidenciaintervallum; T2DM = 2-es típusú cukorbetegség

tározására szolgáló korrigáló tényezőt” alkalmaztuk, egyedül a biztosan az emlőtumorra visszavezethető halálozásra vonatkozó eredményeket ismertetjük. A T2DM és a thrombocytosis hatását először az „egyszerúbb”, önálló hatásokat vizsgáló modellekkel, majd az ún. összetett - vagyis több, a jelen esetben két magyarázó változóval illesztett - modelleken mutatjuk be. A túlélési modellek eredményeit a 3. táblázatban foglaltuk össze.

Abban az esetben, ha az emlőtumoros megbetegedéshez T2DM is társul, a T2DM jelentősen rontja a betegek életkilátásait; a biztosan az emlőtumorra visszavezethető halálozás magasabb a T2DM-csoportban. A rövidebb túlélési időnek $\mathrm{kb}$. háromszor nagyobb rizikója figyelhető meg (hazárd ráta [HR]: 2,87, 95\%-os konfidenciaintervallum $(\mathrm{KI})$ : 1,43-5,78, $\mathrm{p}=0,0032$ ) a nem-DMcsoporthoz képest (2. ábra). Az emlőtumor diagnózisakor megfigyelt thrombocytaszámoknak nem igazolható a túlélési időt befolyásoló önálló hatása, legyenek azok akár az abszolút számokkal jellemezve vagy 400 G/l határérték alapján: van vagy nincs thrombocytosis szerint csoportosítva (3. táblázat).
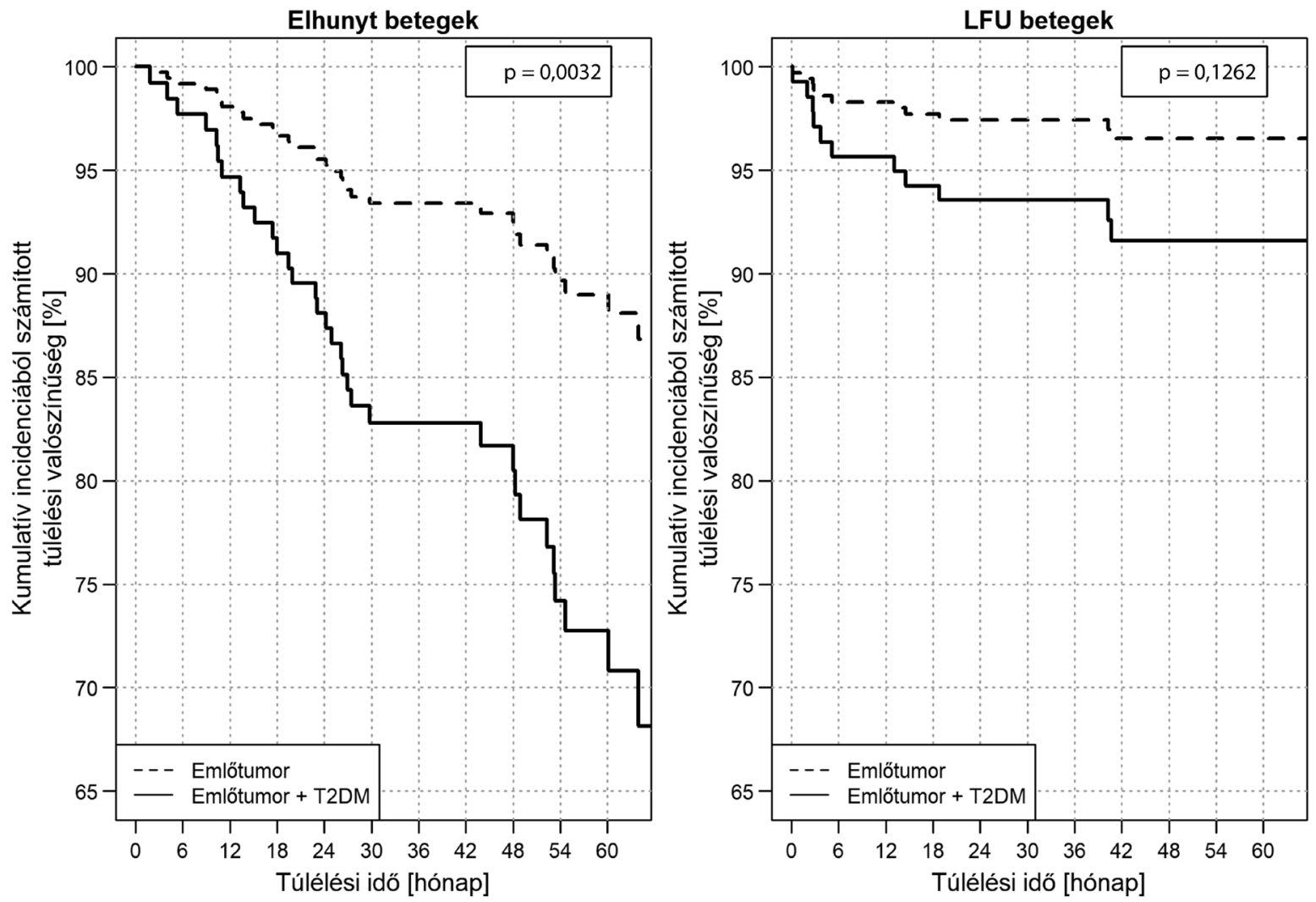

2. ábra $\quad$ A 'competing risk' modell alapján, a becsült kumulatív incidencia függvényekből számított túlélési görbék a két eseményre (beteg emlőtumor miatti halálozása, „lost-to-follow-up”: LFU) külön-külön. A vizsgált emlőtumoros nőkben a 2-es típusú cukorbetegségben (T2DM) is szenvedő nőknél a rövidebb túlélési idő rizikója szignifikánsan magasabb, közel háromszoros ( $\mathrm{p}=0,0032)$, mint a nem cukorbetegek esetében. Az LFU bekövetkezésére a T2DM-nek nincs kimutatható hatása $(\mathrm{p}=0,1262)$ 
A T2DM és a thrombocytaszám tumoros túlélésre gyakorolt összetett hatásait vizsgálva (3. táblázat):

- A thrombocytosis / abszolút thrombocytaszámok se nem növelik, se nem csökkentik szignifikánsan a betegek túlélési idejét.

- A diabetes túlélésre gyakorolt rizikója közel háromszor magasabb ( $\mathrm{p}=0,0027$ és $\mathrm{p}=0,0019)$.

- Ha a T2DM és a 400 G/l feletti thrombocytosis ugyanazon betegben állna fenn, a két kórállapot együttes hatása - túlélési modellünk alapján - már közel az ötszörösére (HR: 4,83) növelné a korábbi halálozás rizikóját.

\section{Megbeszélés}

A tumoros megbetegedésekhez társult thrombocytosisban a betegek túlélési esélyei jellemzően rosszabbak [7]. Számos tumortípusban igazolták, hogy jelentősen megnő a thrombocytosis aránya, ilyenek például a gastrointestinalis tumorok $[18,28]$, illetve az endometrium[30] és ovariumtumorok [31]. A thrombocytosis kialakulásának számos etiológiai oka lehet, sok tumortípusnál általánosan jellemző a vérzés következtében kialakuló szekunder, illetve a paraneoplasticus thrombocytosis [31, 32]. Az emlőtumorok és a thrombocytosis kapcsolatáról nincs egységes konszenzus: egyes szerzők szerint csak nagyon ritkán vagy gyakorlatilag nem is alakul ki thrombocytosis emlőtumorban $[7,8]$. Más közlemények viszont felvetették ennek szöges ellenkezőjét is [33], de fontos kiemelni, hogy a vizsgálatban a thrombocytosis határértékét $(350 \mathrm{G} / 1$ felett) a normáltartományon belül [29] határozták meg. Egy 2017-ben megjelent tanulmány szerint az inflammatoricus emlőtumorokban, habár csupán az esetek kevesebb mint 5\%ában, de a többi tumortípushoz képest szignifikánsan gyakrabban alakul ki thrombocytosis [9]. Jelen vizsgálatunk eredményei alapján az elemzésbe bevont betegek csupán 5,1\%-ánál volt igazolható thrombocytosis (400 G/1 felett), ami sem laboratóriumi, sem anamnesztikus, sem pedig túlélésbeli különbségeket nem okoz a thrombocytosisos és a nem thrombocytosisos betegek között.

A T2DM is jellemzően negatívan befolyásolja a tumoros betegek túlélését. Az egészséges populációhoz képest cukorbetegekben szignifikánsan gyakrabban figyelték meg számos tumoros megbetegedés, mint például az emlő, a vastag- és végbél, illetve a hasnyálmirigy tumorának kialakulását $[12,13,15,16]$. Az emlőtumorok kb. 20\%-kal gyakrabban alakulnak ki T2DM-ben, mint a nem cukorbetegekben [13]. A megnövekedett incidencia hátterében a cukorbetegség hatásai közül a megnövekedett mennyiségú inzulinnak és az IGFl-nek, illetve a tartósan nem megfelelő glykaemiás kontroll következtében kialakult hyperglykaemia hatásának tulajdonítják a legnagyobb szerepet $[3,19,20]$. A két betegség közötti szoros kapcsolatot erősíti az a tény is, hogy már a praediabeteses állapotokban is emelkedett az emlőtumorok kialakulásának kockázata $[34,35]$ az egészséges populá- cióhoz képest. Megfigyelték továbbá, hogy emlőtumoros betegben a tumor diagnózisát követően a T2DM 1-5 éven belüli megjelenése is gyakoribb, mint az azonos korú, de egészséges személyekben [36]. A jelen vizsgálatba bevont nők átlagos túlélési ideje a cukorbeteg és nem cukorbeteg vizsgálati csoportok között - a Welchféle kétmintás t-próba alkalmazásával - nem különbözött szignifikánsan. Fontos azonban kiemelnünk, hogy az általunk vizsgált időszak alatt $2,5 \times$ több cukorbeteg hunyt el. Mindezek indokolták a pontosabb túlélésre vonatkozó korszerú modellezési eljárások alkalmazását, melyek eredménye alapján a T2DM-nek a túlélést negatívan befolyásoló hatását igazoltuk: az emlőtumor diagnózisa előtt kialakult cukorbetegség rövidebb túlélési időt prognosztizál, melynek rizikója háromszor magasabb.

Régóta fennálló vita tárgya, hogy a cukorbetegségben is szenvedő emlőtumoros nőkben a daganat klinikopatológiai tulajdonságai különböznek-e vagy sem [37, 38]. Több munkacsoport megfigyelése alapján a cukorbeteg és emlőtumoros nőkben alacsonyabb a progeszteron-, ösztrogén- és HER2-pozitív tumorok aránya [37]. $\mathrm{Az}$ emlőtumor szövettani stádiumával kapcsolatban azonban eltérő eredmények láttak napvilágot: míg egyes szerzők eredményei alapján a tumorstádiumok eltérőek a cukorbetegek és a nem cukorbetegek között [38], addig más vizsgálatok során ez nem volt igazolható [37]. A munkacsoportunk által vizsgált magyar populációban a cukorbetegek körében az emlőtumorok előrehaladottabb klinikai stádiumát figyeltük meg, a két csoport között azonban nem volt különbség a progreszteron- és / vagy ösztrogén- és/vagy HER2-receptort expresszáló tumorok arányaiban.

Az 50 évnél fiatalabb nőknél 17 esetben figyeltünk meg tripla negatív emlötumort, a teljes vizsgálati populációban pedig összesen 33 esetben; ebből csupán egy beteg tartozott a T2DM-csoportba. A T2DM-csoportban a betegek életkora szignifikánsan magasabb volt, ami összefügg a tripla negatív tumorok alacsonyabb számával is: a tripla negatív emlötumorok - melyek jellemzően rosszabb túlélési esélyeket prognosztizálnak - szignifikánsan gyakoribb kialakulását igazolták 50 évnél fiatalabb nőknél [39].

A T2DM-ben ismerthez hasonlóan [40] a nem metasztatikus emlőtumorokban a különböző cardio- és cerebrovascularis események előfordulási gyakorisága jelentősen magasabb, mint a hasonló korú egészséges populációban [41]. A tumor kialakulását megelőzően lezajlott különböző cardio- és cerebrovascularis események mindkét csoportban relatíve magas számban voltak megfigyelhetők, melyek közül kiemelendő, hogy a T2DM-csoportban az akut myocardialis infarctusok száma szignifikánsan magasabb volt. A KSH 2017. évi adatai alapján a magyar lakosság körében a nők kb. 40\%-a szenved magasvérnyomás-betegségben [2]. A nem-DMcsoportban a betegség előfordulási gyakorisága kb. megfelelt ennek, míg a T2DM-csoportban kb. másfélszeres előfordulását igazoltuk. 
T2DM-ben fokozott thrombocytaaktiváció ismert, ezért a cukorbetegek egy jelentős hányadánál alkalmaznak preventív céllal thrombocytaaggregáció-gátló kezelést is $[42,43]$. A fentieket a jelen populációban is megfigyeltük, a T2DM-csoportban többen álltak preventív aggregációgátló kezelés alatt, mint a nem-DM-csoportban.

Habár számos vizsgálatot végeztek a tumorok és a thrombocytosis, illetve a tumorok és a T2DM közötti kapcsolatok feltárására, mindezek együttes fennállását - munkacsoportunk egy előző, colorectalis tumoros betegek bevonásával végzett retrospektív vizsgálatán kívül [18] - eddig nem vizsgálták. A vizsgálatba bevont cukorbeteg nőknél egy esetben sem fordult elő thrombocytosis, de a túlélési modellek eszköztára lehetőséget biztosít ezek becslésére is: a predikciók alapján a két kórkép együttes fennállásakor a korábbi halálozás rizikója közel az ötszörösére emelkedik. Az igen alacsony előfordulási gyakoriság - melyet több vizsgálat is igazolt korábban [7-9, 33] - és a becsült magasabb rizikó a három kórkép közötti gyenge kapcsolatot valószínúsíti.

Retrospektív vizsgálatunk eredményeit összefoglalva, az emlőtumorban és T2DM-ben is szenvedö nők a nem cukorbetegekhez képest fokozott veszélynek vannak kitéve: szignifikánsan többen és korábban hunytak el, illetve a tumorok klinikopatológiai stádiuma is jellemzően előrehaladottabb volt a cukorbetegekben. A normál magyarországi nőkkel összehasonlítva, az általunk vizsgált személyekben a cukorbeteg nők aránya sem korcsoportonként, sem összesen nem különbözött. A Magyar Radiológusok Társaságának ajánlása alapján [44] az emlőtumorok korai szûrésére évente mammográfia elvégzése javasolt. Számos közlemény hívta már fel korábban is a figyelmet, hogy a magyar nők részvételi aránya ezeken a szüréseken igen alacsony [45]. A cukorbetegeknél igazolt fokozott rizikó, illetve az általunk is megfigyelt roszszabb klinikopatológiai tulajdonságok alapján javasoljuk, hogy mind a családorvosi, mind pedig a diabetológiai szakrendelésen történő kontrollok alkalmával a cukorbeteg nők figyelmét fel kell hívni a rendszeres mammográfiai szűrővizsgálaton történő részvétel fontosságára. Javasoljuk továbbá a T2DM-ben szenvedő betegek felvételét az emlőtumornak fokozottan kitett csoportba, és a magyarországi szakmai ajánlásoknak megfelelően T2DM-ben is már 30 éves kor felett a veszélyeztetett nőkhöz (familiáris emlő- vagy petefészekrák, BRCAl /2mutáció hordozása, kórelőzményben szereplő emlőrák, askenázi zsidó származás, Li-Fraumeni- vagy Cowdenszindróma, korábbi mellkasbesugárzás) [44] hasonlóan legyen indokolt a cukorbeteg nők egy-, de legkésőbb kétévenkénti mammográfiás szürővizsgálata.

Anyagi támogatás: A közlemény megírását, illetve a kapcsolódó kutatómunkát a Nemzeti Kutatási, Fejlesztési és Innovációs Hivatal (projektszám: K-116128) és a Magyar Diabetes Társaság kutatási pályázata támogatta.
H. Z. munkáját a Wörwag Pharma Kft. „Wörwag Kutatási Díj PhD-hallgatók részére" címú pályázata támogatta.

Szerzői munkamegosztás: S. A.: Kutatásvezető, témafelvetés, irodalomkutatás, a kézirat szerkesztése, lektorálása. H. M.: A kézirat szerkesztése, betegadatok gyüjtése, statisztikai elemzés és értékelés. L. J.: A kézirat lektorálása, témafelvetés. H. L.: A kézirat lektorálása, betegadatok leszürése. H. Z.: A kézirat szerkesztése, irodalomkutatás, betegadatok gyưjtése, statisztikai elemzés és értékelés, a közlemény koncepciójának megalkotása. A cikk végleges változatát valamennyi szerző elolvasta és jóváhagyta.

Érdekeltségek: A szerzőknek nincsenek érdekeltségeik.

\section{Irodalom}

[1] Taherian-Fard A, Srihari S, Ragan MA. Breast cancer classification: linking molecular mechanisms to disease prognosis. Brief Bioinform. 2015; 16: 461-474.

[2] Badó K, Boros J, Feldmann K, et al. (eds.) Yearbook of health statistics, 2017. [Egészségügyi statisztikai évkönyv, 2017.] Központi Statisztikai Hivatal, Budapest, 2019. [Hungarian]

[3] Joung $\mathrm{KH}$, Jeong JW, Ku BJ. The association between type 2 diabetes mellitus and women cancer: the epidemiological evidences and putative mechanisms. Biomed Res Int. 2015; 2015 : 920618.

[4] Tang Y, Wang Y, Kiani MF, et al. Classification, treatment strategy, and associated drug resistance in breast cancer. Clin Breast Cancer 2016; 16: 335-343.

[5] Akram M, Iqbal M, Daniyal M, et al. Awareness and current knowledge of breast cancer. Biol Res. 2017; 50: 33-55.

[6] Hortobágyi GN, Connolly JL, D’Orsi CJ, et al. Breast. In: Amin MB, Edge S, Greene F, et al. (eds.) AJCC Cancer staging manual (8th edition). Springer International Publishing, Chicago, IL, 2017; pp. 589-636.

[7] Bailey SE, Ukoumunne OC, Shephard E, et al. How useful is thrombocytosis in predicting an underlying cancer in primary care? A systematic review. Fam Pract. 2017; 34: 4-10.

[8] Rajkumar A, Szállási A. Paraneoplastic thrombocytosis in breast cancer. Anticancer Res. 2013; 33: 4545-4546.

[9] Harano K, Kogawa T, Wu J, et al. Thrombocytosis as a prognostic factor in inflammatory breast cancer. Breast Cancer Res Treat. 2017; 166: 819-832.

[10] Ogurtsova K, da Rocha Fernandes JD, Huang Y, et al. IDF Diabetes Atlas: Global estimates for the prevalence of diabetes for 2015 and 2040. Diabetes Res Clin Pract. 2017; 128: 40-50.

[11] International Diabetes Federation. IDF Diabetes Atlas, 8th edition. IDF, Brussels, 2017. Available from: http://diabetesatlas. org/en/ [accessed: November 14, 2017].

[12] Harding JL, Shaw JE, Peeters A, et al. Cancer risk among people with type 1 and type 2 diabetes: disentangling true associations, detection bias, and reverse causation. Diabetes Care 2015; 38: 264-270.

[13] Shlomai G, Neel B, LeRoith D, et al. Type 2 diabetes mellitus and cancer: the role of pharmacotherapy. J Clin Oncol. 2016; 34: 4261-4269.

[14] Giovannucci E, Harlan DM, Archer MC, et al. Diabetes and cancer: a consensus report. CA-Cancer J Clin. 2010; 60: 207-221.

[15] Halmos T, Suba I. The metabolic syndrome and type-2 diabetes mellitus as conditions predisposing for malignant tumors. [A metabolikus szindróma és a 2-es típusú diabetes mellitus mint rosszindulatú daganatra hajlamosító állapotok.] Orv Hetil. 2008; 149: 2403-2411. [Hungarian] 
[16] Rosta A. Diabetes and cancer risk: oncologic considerations. [Diabetes és rákkockázat az onkológus szemszögéből.] Orv Hetil. 2011; 152: 1144-1155. [Hungarian]

[17] Tsilidis KK, Kasimis JC, Lopez DS, et al. Type 2 diabetes and cancer: umbrella review of meta-analyses of observational studies. BMJ 2015; 350: g7607.

[18] Herold Z, Ambrus V, Herold M, et al. The occurrence and impact on survival of type 2 diabetes mellitus and thrombocytosis in colorectal cancer, before and after the surgical resection of the primary tumor. [Colorectalis daganatokban a 2-es típusú cukorbetegség és a thrombocytosis előfordulása, a túlélésre gyakorolt hatásuk, a primer tumor mútéti eltávolítása elött és után.] Orv Hetil. 2018; 159: 756-767. [Hungarian]

[19] Chang YL, Sheu WH, Lin SY, et al. Good glycaemic control is associated with a better prognosis in breast cancer patients with type 2 diabetes mellitus. Clin Exp Med. 2018; 18: 383-390.

[20] Mu L, Zhu N, Zhang J, et al. Type 2 diabetes, insulin treatment and prognosis of breast cancer. Diabetes Metab Res Rev. 2017; 33: e2823.

[21] Oláh A, Kappelmayer J, Nagy J, et al. Recommendation for the testing of estimated GFR, albuminuria and proteinuria for laboratory professionals. [Ajánlás a számított GFR és az albuminuria, proteinuria vizsgálatára laboratóriumi szakemberek számára.] Available from: https://www.doki.net/tarsasag/nephrologia/ upload/nephrologia/document/EPI_GFR_PU_labor_ utm_2011_12_16_jav.pdf?web_id= [accessed: July 2, 2017]. [Hungarian]

[22] Delacre M, Lakens D, Leys C. Why psychologists should by default use Welch's t-test instead of Student's t-test. Int Rev Soc Psychol. 2017; 30: 91-101.

[23] Johnson DH. Statistical sirens: the allure of nonparametrics. Ecology 1995; 76: 1998-2000.

[24] Benjamini Y, Hochberg Y. Controlling the false discovery rate: a practical and powerful approach to multiple testing. J R Stat Soc Ser B-Stat Methodol. 1995; 57: 289-300.

[25] de Wreede LC, Fiocco M, Putter H. mstate: An R package for the analysis of competing risks and multi-state models. J Stat Softw. 2011; 38: 1-30.

[26] Putter H, Fiocco M, Geskus RB. Tutorial in biostatistics: competing risks and multi-state models. Stat Med. 2007; 26: 23892430.

[27] Therneau TM, Grambsch PM. Modeling survival data: extending the Cox model. Springer-Verlag, New York, NY, 2000.

[28] Baranyai Z, Jósa V, Tóth A, et al. Paraneoplastic thrombocytosis in gastrointestinal cancer. Platelets 2016; 27: 269-275.

[29] Bates I. 2 - Reference ranges and normal values. In: Bain BJ, Bates I, Laffan MA. (eds.) Dacie and Lewis practical haematology (12th edition). Elsevier, Amsterdam, printed in China, 2017; pp. 8-17.

[30] Heng S, Benjapibal M. Preoperative thrombocytosis and poor prognostic factors in endometrial cancer. Asian Pac J Cancer Prev. 2014; 15: 10231-10236.

[31] Stone RL, Nick AM, McNeish IA, et al. Paraneoplastic thrombocytosis in ovarian cancer. N Engl J Med. 2012; 366: 610-618.
[32] Wille K, Sadjadian P, Griesshammer M. Thrombocytosis and thrombocytopenia - background and clinical relevance. Dtsch Med Wochenschr. 2017; 142: 1732-1743.

[33] Stravodimou A, Voutsadakis IA. Pretreatment thrombocytosis as a prognostic factor in metastatic breast cancer. Int J Breast Cancer 2013; 2013: 289563.

[34] Crispo A, Augustin LS, Grimaldi M, et al. Risk differences between prediabetes and diabetes according to breast cancer molecular subtypes. J Cell Physiol. 2017; 232: 1144-1150.

[35] Salinas-Martinez AM, Flores-Cortes LI, Cardona-Chavarria JM, et al. Prediabetes, diabetes, and risk of breast cancer: a case-control study. Arch Med Res. 2014; 45: 432-438.

[36] Wang CY, Shih SR, Huang KC. Increasing risk of diabetes mellitus in postmenopausal women with newly diagnosed primary breast cancer. J Diabetes Investig. 2019 Jul 4. [Epub ahead of print]

[37] Bronsveld HK, Jensen V, Vahl P, et al. Diabetes and breast cancer subtypes. PLoS ONE 2017; 12: e0170084.

[38] Hou G, Zhang S, Zhang X, et al. Clinical pathological characteristics and prognostic analysis of 1,013 breast cancer patients with diabetes. Breast Cancer Res Treat. 2013; 137: 807-816.

[39] Dent R, Trudeau M, Pritchard KI, et al. Triple-negative breast cancer: clinical features and patterns of recurrence. Clin Cancer Res. 2007; 13: 4429-4434.

[40] Kiss Z, Rokszin G, Abonyi-Tóth Zs, et al. Dissimilar impact of type 2 diabetes on cardiovascular outcomes according to age categories: a nationwide population study from Hungary. Cardiovasc Diabetol. 2018; 17: 107-114.

[41] Jones LW, Habel LA, Weltzien E, et al. Exercise and risk of cardiovascular events in women with nonmetastatic breast cancer. J Clin Oncol. 2016; 34: 2743-2749.

[42] Santilli F, Pignatelli P, Violi F, et al. Aspirin for primary prevention in diabetes mellitus: from the calculation of cardiovascular risk and risk/benefit profile to personalised treatment. Thromb Haemost. 2015; 114: 876-882.

[43] American Diabetes Association. 10. Cardiovascular disease and risk management: standards of medical care in diabetes -2019 . Diabetes Care 2019; 42(Suppl 1): S103-S123.

[44] Radiológiai Szakmai Kollégium. Guideline of the Ministry of Health for mammographic screening and early breast cancer detection. [Az Egészségügyi Minisztérium szakmai protokollja Mammográfiás emlőszúrésről és a korai emlőrák diagnosztikájáról.]. Available from: https://www.doki.net/tarsasag/radiologia/upload/radiologia/document/RAD_mammografias_ emloszures_2008.pdf [accessed: July 17, 2019]. [Hungarian]

[45] Gresz M. Correlations between malignant breast cancer and breast screening in Hungary, based on the National Health Insurance Fund database. [Az emlő rosszindulatú daganata és az emlőszúrés viszonya Magyarországon az Országos Egészségbiztosítási Pénztár adatainak tükrében.] Orv Hetil. 2012; 153: 1745-1751. [Hungarian]

(Somogyi Anikó dr., Budapest, Szentkirályi utca 46., 1088 e-mail: somogyi.aniko@med.semmelweis-univ.hu)

A cikk a Creative Commons Attribution 4.0 International License (https://creativecommons.org/licenses/by/4.0/) feltételei szerint publikált Open Access közlemény, melynek szellemében a cikk bármilyen médiumban szabadon felhasználható, megosztható és újraközölhetö, feltéve, hogy az eredeti szerző és a közlés helye, illetve a CC License linkje és az esetlegesen végrehajtott módosítások feltüntetésre kerülnek. (SID_1) 